\title{
Equilibrium and Kinetic Study of the Removal of Cadmium from the Human Blood Plasma Using Dried Allium cepa Biomass
}

\author{
Jibunor Victor Udoka ${ }^{1,}$, Maaji Sheba Paul ${ }^{2}$, Nnachi Chima ${ }^{3}$ \\ ${ }^{1}$ Department of Chemistry, Faculty of Physical Sciences, Ahmadu Bello University, Zaria, Nigeria \\ ${ }^{2}$ Department of Chemical Sciences, Faculty of Pure and Applied Sciences, Federal University Wukari, Wukari, Nigeria \\ ${ }^{3}$ Department of Chemistry, Faculty of Physical Sciences, Federal University Dutsin-Ma (FUDMA), Dutsin-Ma, Nigeria
}

Email address:

udokajibunor@gmail.com (J. V. Udoka)

${ }^{*}$ Corresponding author

\section{To cite this article:}

Jibunor Victor Udoka, Maaji Sheba Paul, Nnachi Chima. Equilibrium and Kinetic Study of the Removal of Cadmium from the Human Blood Plasma Using Dried Allium cepa Biomass. American Journal of Science, Engineering and Technology. Vol. 6, No. 2, 2021 , pp. $20-26$. doi: $10.11648 /$ j.ajset.20210602.11

Received: March 16, 2021; Accepted: March 27, 2021; Published: April 30, 2021

\begin{abstract}
The therapeutic importance of Allium cepa has been reported in previous studies. However, little has being known of its efficiency to remove heavy metal from the human blood plasma. Thus this study seeks to investigate the efficiency of Allium cepa biomass in detoxification of Cadmium ions from aqueous solution of human blood plasma in-vitro. The biosorbent was prepared and identified using FTIR which revealed the presence of carbonyl group, amide group, sulphoxide group, ether and aromatic groups. The optimum sorption was investigated and the experimental data revealed an equilibrium $\mathrm{pH} 4$, optimum $\mathrm{Cd}^{2+}$ concentration $70 \mathrm{mgL}^{-1}$ and optimum biosorbent dose $0.80 \mathrm{~g}$ were obtained and used to study the equilibrium sorption rate which occurred at 80 mins with $99.98 \%$ removal at ambient temperature. The experimental data fitted Pseudo Second order kinetic as indicated by the correlation coefficient value $\left(\mathrm{R}^{2}\right)=0.9961$ with a rate constant $\mathrm{K}_{2}=0.3730 \mathrm{~g} \cdot \mathrm{mg}^{-1} \cdot \mathrm{min}^{-1}$. The experimental data conforms to Freundlich isotherm and Jovanovis isotherm, however Freundlich isotherm showed best fit with correlation coefficient $\left(\mathrm{R}^{2}\right)=0.632$, sorption capacity $(\mathrm{KF})=3.3113$ and sorption intensive $(\mathrm{n})=1.870$. The separation factor of the Langmuir isotherm $(\mathrm{RL})=0.0141$, which suggests that the overall adsorption process was favourable.
\end{abstract}

Keywords: Allium cepa, Biosorption, Flory-Huggins Isotherms, Freundlich Isotherms, Jovanovic Isotherms, Langmuir Isotherms, Kinetic Models, Toxic Metal

\section{Introduction}

Health challenges often arise due to the presence of toxic metals present in industrial chemicals which adversely affect animals and human lives. Toxic metals (Cadmium) are harmful been adduced to their ability to bio-accumulate in various plants and body parts due to their non-biodegradable nature [1]. These metals have a wide application in agriculture as fungicides, pesticide and herbicide to control pest and improve agricultural yield. Exposure to these metals even at low concentration often causes a wide range of illness such as nausea, vomiting, destruction of the blood cell, damage liver and kidney failure to mention but a few. The metals enter the human body through inhalation, drinking of contaminated water and consumption of contaminated plant and animal. These metal are often transported to various body part through the human blood plasma and tend to bind to protein cite by displacing the essential metals from their natural binding cite in the body thereby causing health challenges [2]. Techniques such as adsorption, coagulation, biosorption, solvent extraction, oxidation, reverse osmosis and phytoremediation have being employed in the removal of these metals. However, increase in the amount of hazardous chemicals makes these conventional techniques insufficient.

Biosorption technology exploits biomaterials in the elimination of toxic metals from aqueous solution via physiochemical and/or metabolically mediated pathways. This practice has being employed for a while asit provides an 
eco-friendly, effective and low cost material option. Amongst these biomaterials are Allium cepa, which is vegetable plant widely consumed for it therapeutic important. They have being reported to contain health promoting phytochemicals (quercetin, disulphides, trisulphides and vinlydithiins), acrid and strong antioxidants [3]. They are important in disease prevention, tracking free radicals in the body and preventing blood platelets from sticking together and forming clots and reduce blood pressure [4].

The human blood plasma is a component of the human blood. It makes up 55 per cent of total blood volume. It helps in suspension of the blood cells and also in the transportation of essential nutrients, antibodies, unwanted materials and toxic substances around the body. Several studies have being carried out utilizing plants and animal remaining in heavy metal removal. For instance, Chromium (IV) adsorption from aqueous solution by Leucaenaleucocephala seed shell [5]; Biosorption of heavy metals from aqueous solution using Streptomyces rimosus biomass [1]; Lead biosorption from aquesous solution by waste biosorbent from derived from biotrickling filter: Kinetics and, isotherm and thermodynamics [2]; Multicomponent isotherm for biosorption of $\mathrm{Zn}$ (II), Co (II) and $\mathrm{Cd}(\mathrm{II})$ from temary mixture onto pretreated dried Aspergillus niger biomass [6]; Cadmium biosorption from aqueous using Aspergillus cristatus [7]; Evaluation of Ulva Fasciata and Sargassumsp for the biosorption of $\mathrm{Cu}^{2+}$ from aqueous solution [8]; amongst others. This study seeks to investigate the kinetics and equilibrium of the decontamination of cadmium from human blood fluid utilizing dehydrated Allium cepa biomass. The equilibrium $\mathrm{pH}$, initial $\mathrm{Cd}^{2+}$ concentration and biosorbent dose will be established and employed to study the rate of $\mathrm{Cd}^{2+}$ removal from human blood fluid. The experimental date obtained will be fitted into Freundlich Isotherm, Freundlich isotherm, Jovanovic Isotherm and Langmuir Isotherm. The kinetic study was investigated using pseudo first and second order kinetic model.

\section{Materials and Methods}

\subsection{Collection and Preparation of Sample Materials and Chemicals}

All chemicals used were of annular grade. The stock solution of $\mathrm{Cd}^{2+}$ was prepared in $1.0 \mathrm{gL}^{-1}$ concentration using $3 \mathrm{CdSO}_{4} .8 \mathrm{H}_{2} \mathrm{O}$ then diluted to the required concentration prior to analysis (Abdel-Atyet. al. 2013). $0.1 \mathrm{molL}^{-1} \mathrm{HNO}_{3}$ and $0.1 \mathrm{molL}^{-1} \mathrm{NaOH}$ were employed to adjust the $\mathrm{pH}$ Value of the aqueous solution. The human blood sample from which the plasma was extracted and used for the study was collected from the Department of Hematology, Ahmadu Bello University, Zaria. Allium cepa sample was collected from samaru market and taken to the Department of Chemistry Multi User Research Science Laboratory (MURSL) prior to analysis. Preparation and characterization of samples (Allium cepa and Human Blood plasma) has being reported by previous study [9].

\subsection{Biosorption Experiment}

\subsubsection{Study of Equilibrium $\mathrm{pH}$}

The equilibrium $\mathrm{pH}$ was studied at varying $\mathrm{pH}$ range $(0.5-$ 10) by introducing $0.80 \mathrm{~g}$ of biosorbent into $100 \mathrm{~cm}^{3}$ conical flask containing $50 \mathrm{~cm}^{3}$ aqueous solution composed of human blood plasma and $70 \mathrm{mgL}^{-1} \mathrm{Cd}^{2+}$ concentration. The mixture was adjusted to the desired $\mathrm{pH}$ using $0.1 \mathrm{HNO}_{3}$ and $0.1 \mathrm{NaOH}$ then agitated for 120 mins at $150 \mathrm{rpm}$ using a rotary shaker [10]. The filtrate separated from the mixture using Whatman No 11 filter paper, digested and analyzed for residual $\mathrm{Cd}^{2+}$ concentration using Atomic Adsorption Spectrophotometer (AAS).

\subsubsection{Study of Equilibrium Concentration}

The equilibrium concentration was studied at varying metal ion concentration $(20-100) \mathrm{mgL}^{-1}$ by introducing 0.80 $\mathrm{g}$ of biosorbent into $100 \mathrm{~cm}^{3}$ conical flask contain $50 \mathrm{~cm}^{3}$ aqueous solution composed of human blood plasma and 20 $\mathrm{mgL}^{-1} \mathrm{Cd}^{2+}$ concentration. The mixture was adjusted to the equilibrium $\mathrm{pH}$, then agitated for $120 \mathrm{mins}$ at $150 \mathrm{rpm}$ using a rotary shaker [9]. After the preset contact time, the filtrate separated from the mixture using Whatman No 11 filter paper, digested and analyzed for residual $\mathrm{Cd}^{2+}$ concentration using Atomic Adsorption Spectrophotometer (AAS).

\subsubsection{Study of Equilibrium Biosorbent Dosage}

The equilibrium biosorbent dosage was investigated at varying biosorbent dosage $(0.20-1.00) \mathrm{g}$ by introducing $0.20 \mathrm{~g}$ of biosorbent into $100 \mathrm{~cm}^{3}$ conical flask containing 50 $\mathrm{cm}^{3}$ aqueous solution composed of human blood plasma and equilibrium metal ion concentration. The mixture adjusted to equilibrium $\mathrm{pH}$, then agitated for $120 \mathrm{mins}$ at $150 \mathrm{rmp}$ using a rotary shaker [11]. After the preset contact time, the filtrate separated from the mixture using Whatman No 11 filter paper, digested and analyzed for residual $\mathrm{Cd}^{2+}$ concentration using Atomic Adsorption Spectrophotometer (AAS).

\subsubsection{Study of Equilibrium Contact Time}

The rate of biosorption was studied at varying contact time $(10$ - 120) mins, by the introduction of equilibrium biosorbent dose into $100 \mathrm{~cm}^{3}$ conical flask, containing a solution composed of $50 \mathrm{~cm}^{3}$ human blood plasma solution and equilibrium metal ion concentration. The mixture adjusted to equilibrium $\mathrm{pH}$ using $0.1 \mathrm{HNO}_{3}$ and $0.1 \mathrm{NaOH}$, then agitated for various contact time $\left(\begin{array}{ll}10 & -120\end{array}\right)$ mins respectively [12]. After the preset contact time, the filtrate separated from the mixture using Whatman No 11 filter paper, digested and analyzed for residual $\mathrm{Cd}^{2+}$ concentration using Atomic Adsorption Spectrophotometer (AAS).

\subsection{Data Analysis}

The percentage removal of $\mathrm{Cd}^{2+}$ was calculated using equation 1

$$
\% \mathrm{R}=\mathrm{Co}-\mathrm{Ce} / \mathrm{Co} \times 100
$$

Where $\mathrm{C}_{o}$ and $\mathrm{C}_{\mathrm{e}}$ represent the initial and final metal ion 
concentration $\left(\mathrm{mg} / \mathrm{L}^{-1}\right)$, present in the human blood plasma solution respectively [10].

The amount of metal ion absorbed per unit mass $\left(\mathrm{q}_{\mathrm{e}}\right)$ is calculated using equation 2 .

$$
\mathrm{q}_{\mathrm{e}}=(C o-C e) \mathrm{V} / M
$$

where $C_{i}$ and $C_{e}$ represents the initial and final (Equilibrium) metal ion concentration after time $\mathrm{t}$ min., $\mathrm{V}$ represents the volume of human blood plasma in $\mathrm{Cm}^{3}$ and $\mathrm{M}$ is the mass of adsorbent in gram [10].

\subsection{Adsorption Kinetics}

The adsorption kinetics was investigated by employing the pseudo first and second order kinetic models to analyze metal ion uptake from the aqueous solution at different time intervals. When plotted, the linearity indicates if the models suitably describe the adsorption process [13].

The pseudo first order kinetic model is expressed in equation 3 .

$$
\log \left(\mathrm{q}_{\mathrm{e}}-\mathrm{q}_{\mathrm{t}}\right)=\log \left(\mathrm{q}_{\mathrm{e}}\right)-\mathrm{K}_{1} / 2.303
$$

Where, $\mathrm{q}_{\mathrm{e}}$ and $\mathrm{q}_{\mathrm{t}}$ represents the sorption capacity at equilibrium and at time $\mathrm{t}$, respectively $\left(\mathrm{mgm}^{-1}\right)$ and $\mathrm{K}_{1}$ is the rate constant of pseudo first order sorption (L.min ${ }^{-1}$ ) [14]. A plot of $\log \left(q_{e}-q_{t}\right)$ against $t$ give a straight line with $\log \left(q_{e}\right)$ as slope and $\mathrm{K}_{1}$ as intercept.

The Pseudo second order kinetic is expressed in equation 4.

$$
\frac{t}{q t}=\left(\frac{1}{K_{2} q_{e}^{2}}\right)+\left(\frac{t}{q_{e}}\right)
$$

Where qe and qt represents the sorption capacity at equilibrium and at time $t,\left(\mathrm{mgg}^{-1}\right)$ respectively, while $\mathrm{K}_{2}$ is the pseudo second order kinetic rate constant $\left(\mathrm{g} \cdot \mathrm{mg}^{-1} \cdot \mathrm{min}^{-1}\right)$ [15].

\subsection{Adsorption Isotherms}

The adsorption isotherm describes the interaction between the adsorbate in the solution and the adsorbent to establish equilibrium between the metal ions absorbed and the residual metal ions [16]. However, the potential of two parameter isotherms (Flory-Huggins Model, Freundlich model, Jovanovic model and Langmuir model) were tested to identify the model that best describe the interaction between the metal ions in the solution and the adsorbent.

The linear form of Flory-Huggins is expressed in equation 5.

$$
\log \frac{\theta}{C o}=\log K_{F G}+n \log (1-\theta)
$$

Where $K_{F G}$ is Flory-Huggins equilibrium constant $\left(\mathrm{Lmg}^{-1}\right)$, $\theta=\left(1-\mathrm{C}_{\mathrm{e}} / \mathrm{C}_{\mathrm{o}}\right)$ represents fractional coverage, and $\mathrm{n}$ is the interaction energy between the absorbed molecules [17]. A plot of $\log \frac{\theta}{C o}$ against $\log (1-\theta)$ is used to ascertain the value of $\mathrm{n}$ and $\mathrm{K}_{\mathrm{FG}}$ as the slope and intercept respectively.

The Gibbs free energy is calculated using equation 6 .

$$
\Delta \mathrm{G}=\text {-RT } \operatorname{InK}_{\mathrm{FH}}
$$

The linear form of Freundlich isotherm is expressed in equation 7 .

$$
\log \mathrm{q}_{\mathrm{e}}=\log \mathrm{K}_{\mathrm{F}}+\frac{1}{n} \log \mathrm{C}_{\mathrm{e}}
$$

where $K_{F}$ is the Freundlich adsorption capacity $(\mathrm{L} / \mathrm{mg})$ and $1 / \mathrm{n}$ represent the adsorption intensity, which also is an indication of the relative distribution of the energy level of heterogeneity of the active cite on the adsorbent. A plot of $\log \mathrm{q}_{\mathrm{e}}$ against $\log \mathrm{C}_{\mathrm{e}}$ will produce a straight line with slope $1 / \mathrm{n}$ and intercept $\mathrm{K}_{\mathrm{F}}$ [18].

The linear form of Jovanovic isotherm is expressed in equation 8

$$
\text { In } q_{e}=\operatorname{In} q_{\max }-\mathrm{K}_{\mathrm{f}} \mathrm{C}_{\mathrm{e}}
$$

where $q_{e}(\operatorname{mgg}-1)=$ represent the amount of $\mathrm{Cd}^{2+}$ on the biosorbent at equilibrium, $\mathrm{q}_{\max }$ represents the maximum metal ions absorbed obtained from a plot of In $q_{e}$ against $\mathrm{C}_{\mathrm{e}}$, $\mathrm{K}_{\mathrm{j}}$ represents the Jonanovic isotherm constant [19].

The linear form of Langmuir isotherm is expressed in equation 9 .

$$
\frac{C e}{Q e}=\frac{1}{Q m} C e+\frac{1}{K l . Q m}
$$

Where, $\mathrm{q}_{\mathrm{e}}$ represents equilibrium conc. of metal $\mathrm{Cd}^{2+}$ in solid phase, $\mathrm{C}_{\mathrm{e}}$ represents equilibrium conc. of metal $\mathrm{Cd}^{2+}$ in liquid, $\mathrm{Q}_{\mathrm{m}}$ represents Langmuir constant while $\mathrm{K}_{\mathrm{L}}$ represents Langmuir sorption equilibrium constant [20]. A plot of $C_{e} / Q_{e}$ against $C_{e}$ gives straight line from which $\mathrm{Q}_{\mathrm{m}}$ and $\mathrm{K}_{\mathrm{L}}$ can be calculated from the slope and intercept respectively. The isotherm further predicts the affinity between the metal ions in aqueous solution and the biosorbent as expressed in equation 10 .

$$
\mathrm{R}_{\mathrm{L}}=\frac{1}{1+\mathrm{KLCo}}
$$

Where $\mathrm{R}_{\mathrm{L}}$ represents the separation factor and $\mathrm{C}_{\mathrm{o}}$ represents the initial metal ion concentration in the aqueous solution. A favorable adsorption is recorded when value of $R_{L}$ is in between 0 and 1 . Thus $R_{L}>1$ is an unfavourable adsorption. However were $\mathrm{R}_{\mathrm{L}}=1$ suggests linear adsorption and $\mathrm{R}_{\mathrm{L}}=0$ suggests irreversible adsorption [21].

\subsection{FTIR Spectroscopy}

FTIR spectra of adsorbent before and after $\mathrm{Cd}^{2+}$ binding were recorded to identify the active cite believed to be responsible for the metal ion uptake as reported in previous study [22].

\section{Result and Discussion}

\subsection{FTIR Spectroscopy}

The FTIR spectra of the adsorbent before and after biosorption are presented in Figure 1 and Figure 2 respectively. The result revealed a general shift in the peaks from 3272.6 $\mathrm{cm}^{-1}-3268.9 \mathrm{~cm}^{-1}, 1636.3-1625.1 \mathrm{~cm}^{-1}, 1364.2 \mathrm{~cm}^{-1}-$ $1319.5 \mathrm{~cm}^{-1}, 1252.4 \mathrm{~cm}^{-1}-1237.5 \mathrm{~cm}^{-1}, 920.7 \mathrm{~cm}^{-1}-890.8$ $\mathrm{cm}^{-1}$. The general shift in the peak revealed presence of $\mathrm{O}-\mathrm{H}$ stretch of carbonyl group, $\mathrm{C}=\mathrm{O}$ stretch of amide group, $\mathrm{S}=\mathrm{O}$ of 
sulphoxide group, $=\mathrm{C}-\mathrm{O}-\mathrm{O}$ asymmetric stretch of ether group and $=\mathrm{C}-\mathrm{H}$ bend of aromatic group were involved in the overall adsorption process. These functional groups are believed to have participated in the process of adsorption [23].

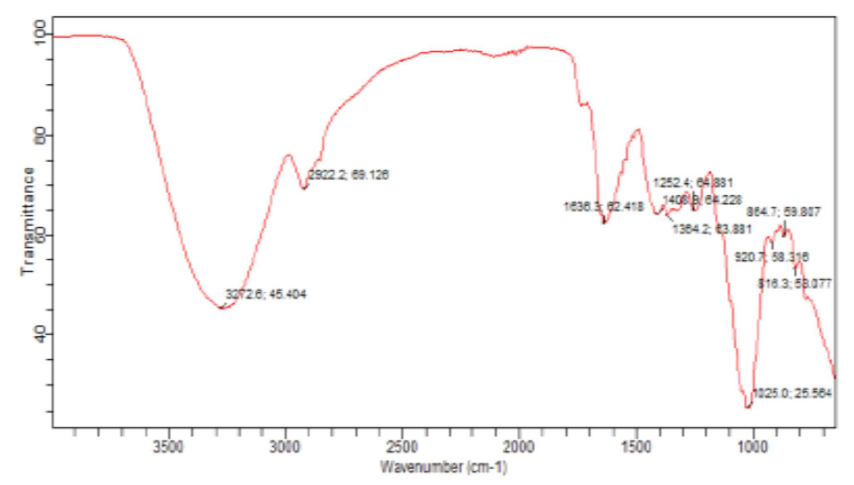

Figure 1. FTIR of Allium Cepa biomass.

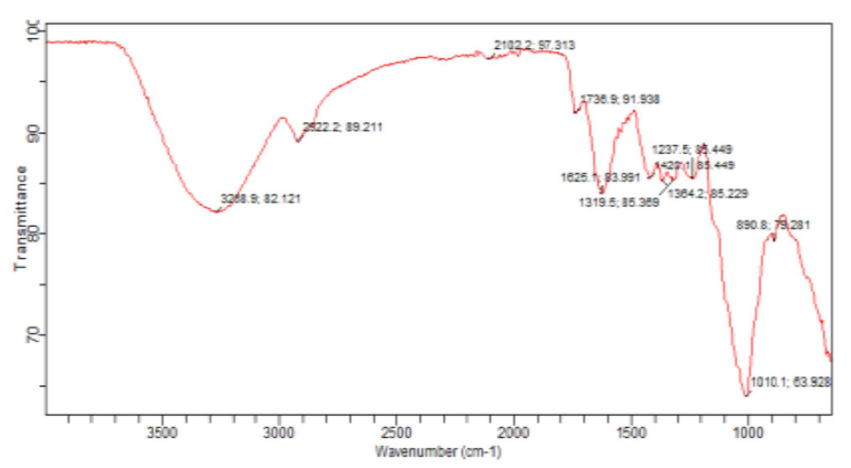

Figure 2. FTIR of $\mathrm{Cd}^{2+}$ loaded Allium cepa biomass.

\subsection{Equilibrium pH}

The $\mathrm{pH}$ of the adsorption process is significant as it directly affect the chemistry of the active cites on the adsorbent with an attendant effect on the adsorption capacity [24]. A plot of percentage removal against varying $\mathrm{pH}$ is presented in Figure 3. The result showed that there was an increase in percentage removal with increase in the $\mathrm{pH}$ of the solution. Equilibrium sorption was attained at $\mathrm{pH} 6$ with $98.446 \%$ removal. Further increased in the $\mathrm{pH}$ of the solution resulted to a decrease in percentage removal. This suggests a low adsorption capacity of the Allium cepa biomass in alkaline medium which is an indication that the solubility of the metal ions in the aqueous solution is affected by the availability of hydrogen ions however, at high $\mathrm{pH}$, these ions are precipitated to hydroxides [25].

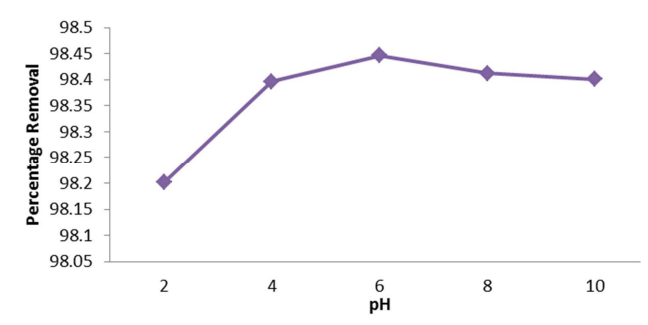

Figure 3. Percentage removal of $\mathrm{Cd}^{2+}$ as a function of $\mathrm{pH}$.

\subsection{Equilibrium Metal Ion Concentration}

Figure 4 represents the plot of percentage removal against varying metal ion concentration. The result revealed a steady increase in percentage removal with an increase in the metal ion concentration. Equilibrium concentration was attained at $70 \mathrm{mgL}^{-1}$ with $98.89 \%$ removal. Further increase in the concentration of metal ions in the solution, resulted to a reduction in the percentage removal. This suggest unavailability of active sites for metal ion uptake due to high saturation of the biding sites by metal ions [26].

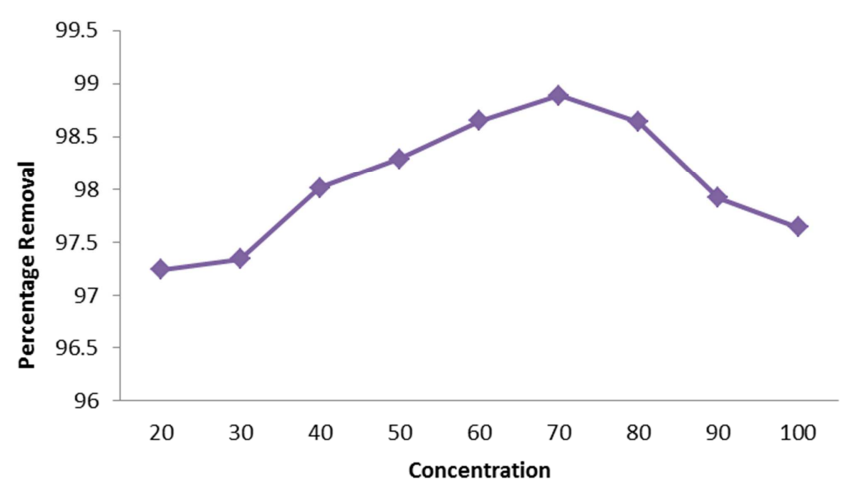

Figure 4. Percentage removal as a function of metal ion concentration.

\subsection{Equilibriumbiosorbent Dosage}

Figure 5 represents a plot of percentage removal against biosorbent dosage. The result revealed an increase in percentage removal with an increase in biosorbent dosage. Maximum sorption was attained at $0.80 \mathrm{~g}$ with $99.92 \%$ removal. Further increase in biosorbent dosage yield a decrease in percentage removal. This is been adduced to high competition for the available metal ions in the solution by the active sites.

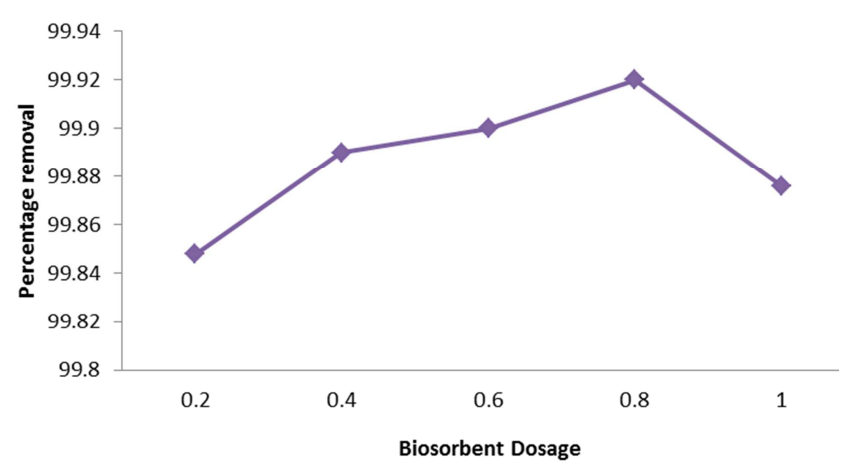

Figure 5. Percentage removal as a function of Biosorbent dosage.

\subsection{Equilibrium Contact Time}

Figure 6 represents a plot of $\%$ removal against contact time. The curve revealed an increase in $\%$ removal with contact time. This increase in $\%$ removal is been adduce to the availability of free biding cites on the adsorbent. Equilibrium sorption was attained at 80 mins with $98.98 \%$ removal. Thereafter, increases in the contact time yield a decrease in the percentage removal. This is an indication of 
unavailability of free binding cites on the adsorbent [9].

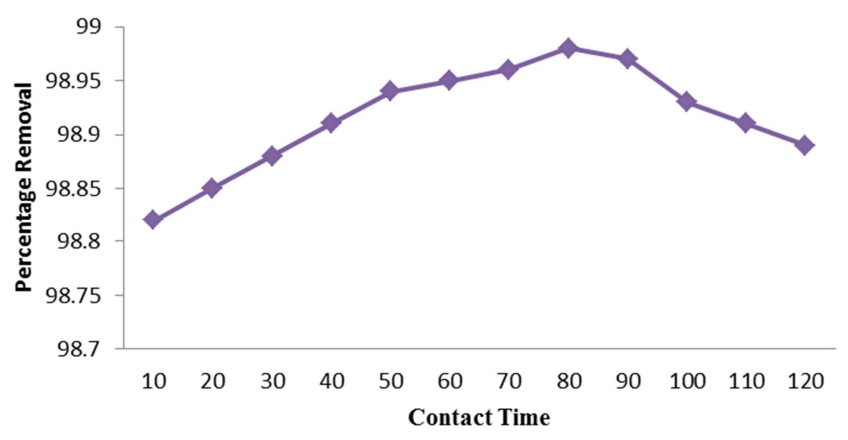

Figure 6. Rate of removal of Cadmium.

\subsection{Adsorption Kinetics}

\subsubsection{Pseudo First Order Kinetic Model}

Figure 7 represents the pseudo first order kinetic model for $\mathrm{Cd}^{2+}$ sorption. The correlation parameters are presented in Table 1. The qevalue $\left(4.37 \mathrm{mgg}^{-1}\right)$ is an indication that significant amount of $\mathrm{Cd}^{2+}$ was adsorbed at equilibrium [14]. The correlation coefficient $\left(\mathrm{R}^{2}\right)=0.869$ suggest that the experimental data fits pseudo first order kinetic model.

\subsubsection{Pseudo Second Order Kinetic}

Figure 8 represents the pseudo second order kinetic for $\mathrm{Cd}^{2+}$ sorption, while the correlation parameters are presented in Table 1. The qe value $\left(3.48 \mathrm{mgg}^{-1}\right)$ indicates that significant amount of $\mathrm{Cd}^{2+}$ was absorbed by the biosorbent.
The correlation coefficient $\mathrm{R}^{2}=1$ indicates that the experimental data fits pseudo second order kinetic model.

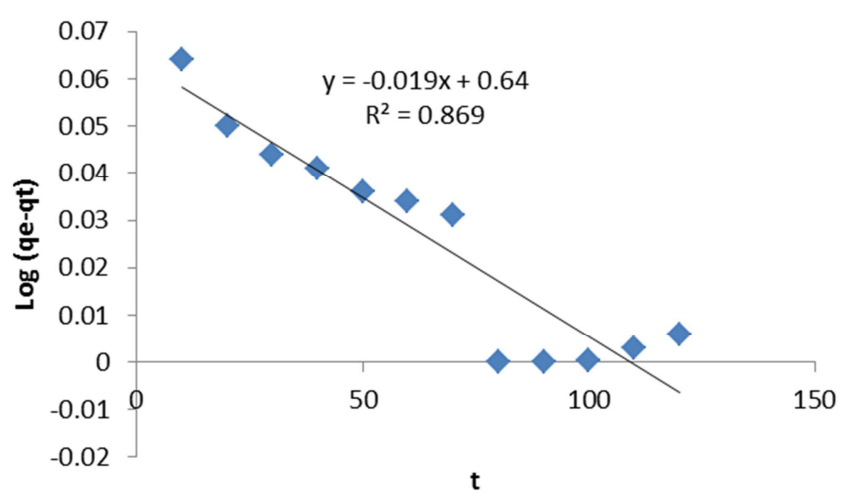

Figure 7. The pseudo first order kinetic model for $\mathrm{Cd}^{2+}$ sorption.

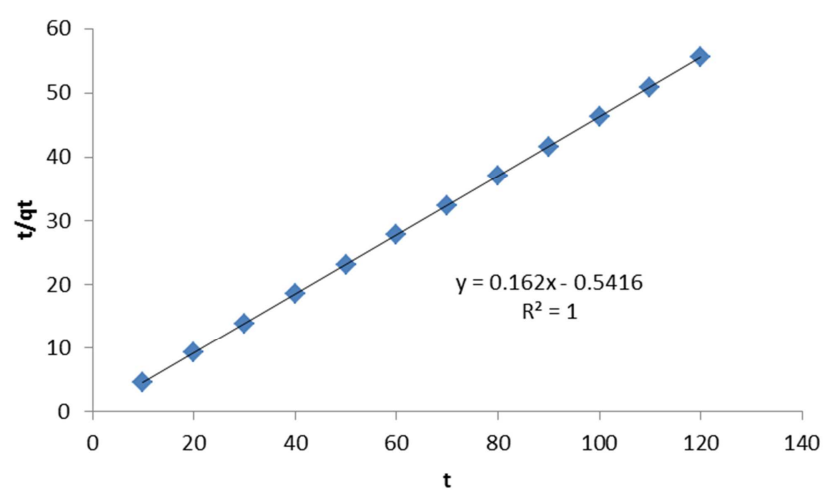

Figure 8. The pseudo second order kinetic for $\mathrm{Cd}^{2+}$ sorption.

Table 1. Adsorption parameters for Pseudo First and Second order kinetic models.

\begin{tabular}{llllll}
\hline \multicolumn{2}{l}{ Pseudo First Order } & \multicolumn{5}{l}{ Pseudo Second Order } \\
\hline Metal ion & $\mathbf{q}_{\mathrm{e}}(\mathbf{m g} / \mathbf{g})$ & $\mathbf{K}_{\mathbf{1}}\left(\mathbf{m i n}^{-\mathbf{1}}\right)$ & $\mathbf{R}^{\mathbf{2}}$ & $\mathbf{q}_{\mathbf{e}}(\mathbf{m g} / \mathbf{g})$ & $\mathbf{K}_{\mathbf{2}}(\mathbf{g} / \mathbf{m g} / \mathbf{m i n})$ \\
\hline $\mathrm{Cd}^{2+}$ & 4.37 & 0.0438 & 0.869 & 3.48 & 0.3730 \\
\hline
\end{tabular}

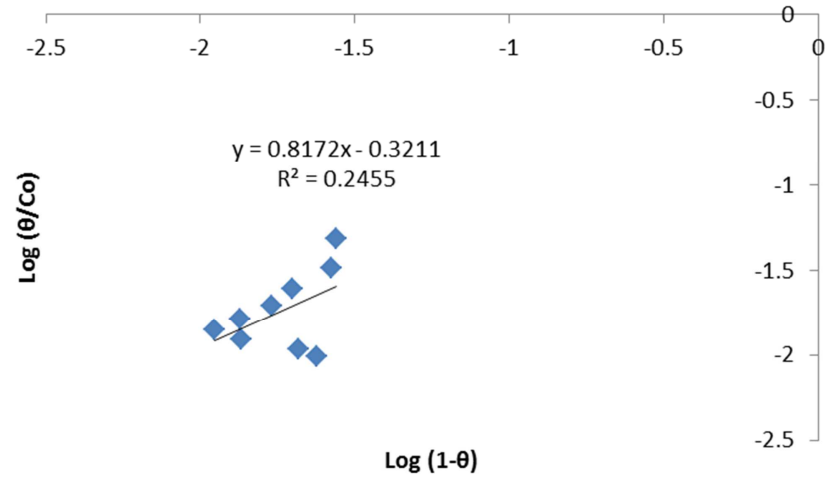

Figure 9. The Flory-Huggins adsorption isotherm for $\mathrm{Cd}^{2+}$ sorption.

\subsection{Adsorption Isotherm}

\subsubsection{Flory-Huggins Isotherm}

The Flory-Huggins adsorption isotherm for $\mathrm{Cd}^{2+}$ sorption is presented in Figure 9. The isotherm parameters are presented in Table 2. The result reveals that the experimental data obtained fits the Flory-Huggins adsorption isotherm as indicated by a correlation coefficient value $\mathrm{R}^{2}=0.245$ while the Flory-Huggins constant $\left(\mathrm{K}_{\mathrm{FG}}\right)=-2.0941$ and the energy of interaction between the absorbed molecules $n=0.817$. This indicates there is a low energy of interaction between the adsorbates [27]. The Gibbs free energy $=55.05 \mathrm{KJmol}^{-1}$ suggests an enthalpy change in the overall physiochemical process.

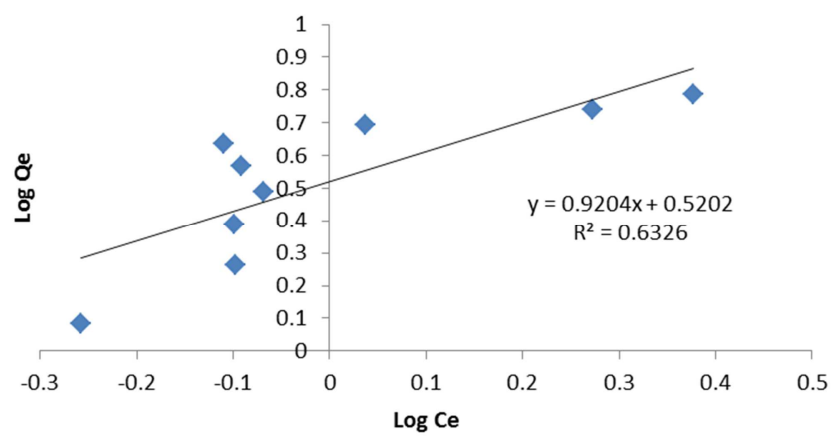

Figure 10. Freundlich Adsorption isotherm for $\mathrm{Cd}^{2+}$ sorption.

\subsubsection{The Freundlich Isotherm}

The Freundlich isotherm for $\mathrm{Cd}^{2+}$ sorption is presented in Figure10. The Freundlich isotherm parameters for $\mathrm{Cd}^{2+}$ sorption are presented in Table 2. The result revealsthat the 
experimental data fits Freundlich isotherm as indicated by the correlation coefficient value $\mathrm{R}^{2}=0.632$. The Freundlich adsorption capacity $\mathrm{K}_{\mathrm{F}}=3.3113$ indicates that a significant amount of $\mathrm{Cd}^{2+}$ was absorbed per site. The adsorption intensity $(\mathrm{n})=1.870 \mathrm{Lmg}^{-1}$ suggests a favorable adsorption of $\mathrm{Cd}^{2+}$ by Allium cepa biomass [28].

\subsubsection{The Jovanovic Isotherm}

The Jovanovic isotherm for $\mathrm{Cd}^{2+}$ sorption is presented in Figure 11. The isotherm parameters are presented in Table 2. The result reveals that experimental data obtained fits Jovanovic adsorption isotherm as indicated by a correlation coefficient $\left(\mathrm{R}^{2}\right)=0.517$. The maximum uptake $\mathrm{q}_{\max }=1.6242$ $\mathrm{mgg}^{-1}$ suggests that a significant amount of $\mathrm{Cd}^{2+}$ was absorbed by the biosorbent. The experimental data also suggests that the biosorbent has a poor retention capacity as indicated by Jovanovic constant $\left(\mathrm{K}_{\mathrm{J}}\right)=0.637$ [19].

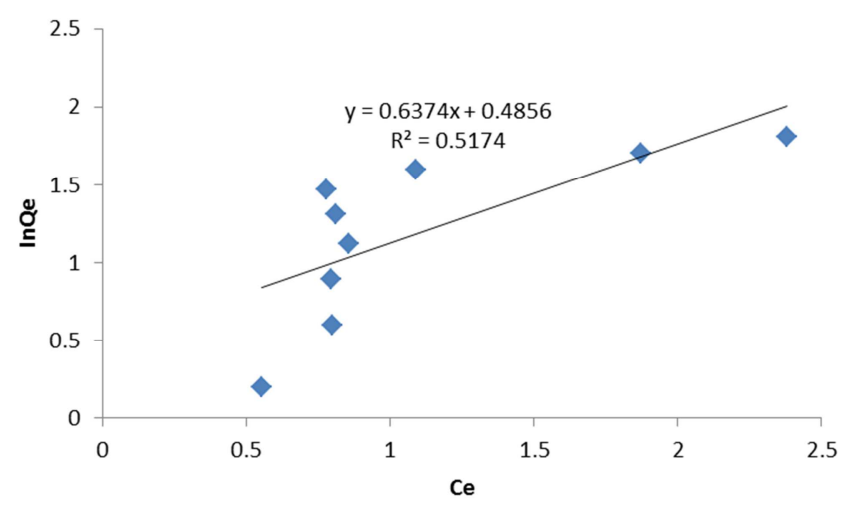

Figure 11. The Jovanovic isotherm for $\mathrm{Cd}^{2+}$ sorption.

\subsubsection{The Langmuir Isotherm}

The Langmuir isotherm for $\mathrm{Cd}^{2+}$ sorption is present in Figure 12. The isotherm's parameters as presented in Table 2. The result revealed that the experimental data did not conform to Langmuir isotherm as indicated by a correlation coefficient $\left(\mathrm{R}^{2}\right)=0.063$. The $\mathrm{Q}_{\max }=2.0739 \mathrm{mgg}^{-1}$ suggests a significant amount of $\mathrm{Cd}^{2+}$ was absorbed by Allium cepa biomass, However $\mathrm{K}_{\mathrm{L}}=0.1203$ suggest a low biosorption capacity of the Allium cepa biomass in removal of $\mathrm{Cd}^{2+}$ from the aqueous solution of human blood plasma. The value of $\mathrm{R}_{\mathrm{L}}=0.0141$ suggests that adsorption process was favourable [29].

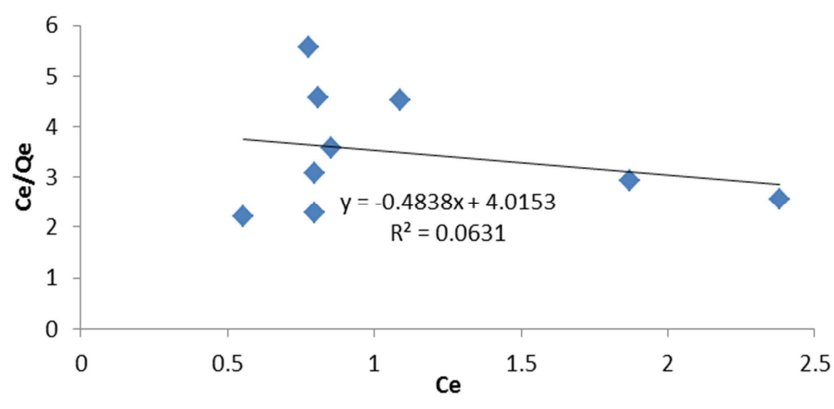

Figure 12. The Langmuir isotherm for $\mathrm{Cd}^{2+}$ sorption.
Table 2. Isotherm Parameters for $\mathrm{Cd}^{2+}$ sorption using Allium cepa biomass.

\begin{tabular}{ll}
\hline Fowler Geggenheim & Freundlich \\
$\mathrm{K}_{\mathrm{FG}}=2.0941$ & $\mathrm{~K}_{\mathrm{F}}=3.3113$ \\
$\mathrm{R}^{2}=0.245$ & $\mathrm{R}^{2}=0.632$ \\
$\mathrm{~N}=0.817$ & $\mathrm{n}=1.870$ \\
\hline & \\
\hline Jovanovic & Langmuir \\
$\mathrm{K}_{\mathrm{J}}=0.637$ & $\mathrm{~K}_{\mathrm{L}}=0.1203$ \\
$\mathrm{R}^{2}=0.517$ & $\mathrm{Q}_{\mathrm{m}}=2.0739$ \\
& $\mathrm{R}^{2}=0.063$ \\
$\mathrm{q}_{\mathrm{max}}=1.6242$ & $\mathrm{R}_{\mathrm{L}}=0.0141$ \\
\hline
\end{tabular}

\section{Conclusion}

The study revealed that the efficacy of Allium cepa for the decontamination of aqueous solution of human blood plasma was dependant on $\mathrm{pH}$, metal ion concentration and biosorbent dosage. The experimental data was well interpreted by the Freundlich isotherm. Though the experimental data did not conform to Langmuir isotherm, however the Langmuir separation factor suggests that the overall adsorption process was favourable. The study further revealed adsorption process followed a pseudo second order reaction path way. The Flory-Huggins isotherm revealed a low energy interaction between the adsorbates in the aqueous solution of human blood plasma. Allium cepa has proven to be an economically available and effective biosorbent for detoxification of

$\mathrm{Cd}^{2+}$ from the aqueous solution of human blood plasma invitro. However further study can be done on chemically modified Allium cepa extract for removal of toxic metals from the human body in-vivo.

\section{References}

[1] Sahmoune, M. N. (2018). Performance of Streptomyces rimosusbiomas in biosorption of heavy metals from aqueous solutions. Microchemicals Journal, 141, 87-95.

[2] Cheng, Y., Yang C., He, H., Zeng, G. Biosorption of Pb (II) ions from aqueous solutions by waste biosorbent from biotrickling filters: Kinetics, isotherms, and thermodynamics. J Environ Eng. 2015; 142, 9.

[3] Olsson, M. E., Gustavsson, K. E., and Vagen, I. M. (2010). Quercetin and isorhamnetin in sweet and red cultivars of onion (Allium cepa L.) at harvest, after curing, heat treatment, and storage. Journal of agricultural and food chemistry, 58(4), pp. 2323-2330.

[4] Diplock, A. T., Aggett, P. J., Ashwel, M., Bornet, F., Fern, E. B. and Roberfroid, M. B. (1999). Scientific concepts of functional foods in Europe: consensus document. British Journal of Nutrition, $81 ; 1$.

[5] Yusuff, A. S. (2018). Optimization of adsorption of Cr (VI) from aqueous solution by Leucaenaleucocephala seed shell activated carbon using design of experiment. Appl Water Sci, 8 (8): 1-11. 
[6] Hajahmadi, Z., Younesi, H., Bahramifar, N., Khakpour, H. and Pirzadeh, K. (2015). Multicomponent isotherm for biosorption of $\mathrm{Zn}$ (II), Co(II) and CD (II) from ternary mixture onto pretreated dried Aspergillus niger biomass. Water Resources and Industry, 11; 71-80.

[7] Hassan, S. W., El-Kassas, H. Y. (2012). Biosorption of cadmium from aqueous solutions using a local fungus. Aspergillus cristatus (Glaucus group). African Journal of Biotechnology, 11 (9); 2276-2286.

[8] Karthikeyan, S., Balasubramania, R. and Iyer, C. S. P. (2007). Evaluation of the marine algseUlva fasciataand sargassum sp. For the biosorption of $\mathrm{Cu}^{2+}$ from aqueous solutions. Bioresource Technology, 98, pp. 452-459.

[9] Ekwumemfbo, P. A., and Jibunor, V. U. (2017). Removal of Lead from human blood plasma using Allium cepa as biosorbent. International Journal of Environmental Science and Development, $8 ; 11$.

[10] Ningchuan, F., Xueyi, G., Sha, L., Yanshu, Z., Jianping, L. (2011). Biosorption of heavy metals from aqueous solutions by chemically modified orange peel. Journal of Hazadous Materials, 185, pp. 49-54.

[11] Rezaei, H. (2016). Biosorption of Chromiumby using Spirulina sp. Arabian Journal of Chemistry, 9 (6), 846-853.

[12] Mishra, A., Dubey, A. and Shinghal, S. (2015). Biosorption of Chromium (VI) from aqueous solutions using waste plant biomass. International Journal of Environmental science and Technology, 12 (4); 1415-1426'.

[13] Al-Dujaili, A. H., Awwad, A. M. and Salem, N. M. (2012). Biosorption of Cadmium (II) onto loquat leaves (Eriobotrya Japonica) and their ash from aqueous solution, equilibrium, kinetics and thermodynamic studies. International Journal of Industrial Chemistry, 3 (1); pp. 1-7.

[14] Fabriano, J., Aline N., Kosasih, J., Yi-Hsu, J., Suryadi, I. (2009). Equilibrium and kinetics studies in adsorption of heavy metals using biosorbent: a summary of recent studies. Journal of harzadous materials, 162 (2), pp. 616-645.

[15] Ho, Y. S. (2006). Second-order kinetic model for the sorption of cadmium onto tree fren: a comparison of linear and nonlinear methods. Water Research, 40 (1), pp. 119-125.

[16] Conrad, K., Hansen, H. C. B. (2007). Sorption of Zinc and Lead on coir. Bioresour. Technol, 98, 89-97.

[17] Amin, M. T., Alazba, A. A. and Shafiq, M. (2015). Adsorptive removal of reactive black 5 from waste water using bentonites clay: isotherms, kinetics and thermodynamics. Sustainability, 7 (11), pp. 15302-15318.
[18] Ebelegi, N. A., Angaye, S. S., Angaye, N. and Wankasi, D. (2017). Removal of congo red from aqueous solutions using fly ash modified with hydrochloric acid. British Journal of Applied Science and Technology, 20 (4), pp. 1-7.

[19] Knaebel, S. K. (2004). Adsorption selection. International Journal of Trend in Research and development, Adsorption Research, Incorporated Dublin, Ohio. 43016.

[20] Abdel-Aty, M. A., Nabila, S., Ammar, H. H., Ghafar, A. and Rizka, A. (2013). Biosorption of cadmium and Lead from aqueous solution by fresh water algae Anabaensphaerica biomass. Journal of Advanced Research, 4, pp. 367-374.

[21] Horsefall, M. and Ayebaemi, I. S. (2005). Effect of temperature on the sorption of $\mathrm{Pb}^{2+}$ and $\mathrm{Cd}^{2+}$ from aqueous solution by caladium bicolor (Wild cocoyam) biomass. Electronic Journal of Biotechnology, 8 (2), pp. 43-50.

[22] Liu, L., Liu, J., Liu, Dai, C., Song, W. and Chu, Y. (2019). Kinetics and equilibrium of $\mathrm{U}$ (VI) biosorption onto the resistant bacterium bacillus amyloliquefaciens. Journal of Environmental Radioactivity, 203, pp. 117-124.

[23] Krishnani, K. K., Meng, X., Christodoulatos, C. and Boddu, V. (2008). Biosorption mechanism of nine different heavy metals onto biomatrix from rice husk. J. Hazard. Mater. 1, pp. 2-10.

[24] Arami, M., Limaee, N. Y. and Mahmoodi, N. M. (2008). Evaluation of the adsorption kinetics and equilibrium for the potential removal of acid dyes using a biosorbent. Chemical engineering Journal, 139 (1), pp. 2-10.

[25] Apiratikul, R. and Murhaba, T. (2004). Songklanakarin, J.Sci. Technol, 26, pp. 199-207.

[26] Sakthi, N., Andal, M., Rengrai, S. and Sillanpaa, M. (2010). Removal of $\mathrm{Pb}$ (II) ions from aqueous solutions using bombaxceiba saw dust activated carbon. Desalination Water and Treatment, 16, pp. 262-270.

[27] Hamdaoui, O. and Naffrechoux, E. (2007). Modelling of adsorption isotherm of phrnol and chlorophenols onto granular activated carbon. Part I. Two-parameter models and equations allowing determination of thermodynamic parameter, Journal of Hazardous Materials, 147 (12), pp. 381-394.

[28] Reddy, K. and Reddy, A. (2010). Removal of heavy metal ions using the chelating polymers derived by the condensation of poly(3-hydroxy-4-acetylphenyl methacrylate)eith different diamines. J. Applied Polymer Science, 88, pp. 414-421

[29] Rahman, M. S. and Islam, M. R. (2009). Effects of pH on isotherms modeling for $\mathrm{Cu}$ (II) ions adsorption using maple wood sawdust. Journal of Chemical Engineering, 149, pp. 273-282. 